\title{
Structure, Conduct and Performance Analysis of Sheabutter Marketing in Oyo State, Nigeria
}

\section{1'OLUGBIRE, OO;, ${ }^{2}$ FAKUNLE, AJ; ${ }^{* 1}$ OGUNTOYE, TO; ${ }^{1}$ OBAFUNSHO, OE}

\author{
${ }^{*}$ Department of Forest Economics and Extension Department, Forestry Research Institute of Nigeria, Jericho, Ibadan, Nigeria \\ ${ }^{2}$ Department of Agricultural Economics, Obafemi Awolowo University, Ile-Ife, Nigeria \\ *Corresponding Author Email: yemmytoye@yahoo.com
}

\begin{abstract}
The study investigated the marketing practices, channels of sheabutter distribution and performance using multi stage sampling techniques to select three local government area for the study in Oyo State. The results showed about $91 \%$ of the respondents were female, the average age of the respondents was 35.5 years. Most $(92.5 \%)$ of the respondents were married with average household size of 8 members. Marketing efficiency was $135 \%$ which implies that the respondents covered the cost of marketing and made a margin above $100 \%$. Unavailability of sheabutter due to deforestation and credit unavailability were the major constraints faced by sheabutter marketers. Furthermore, Household size $(\mathrm{p}=0.005)$, marketing experience and member of organization $(\mathrm{p}=0.001)$, source of shea butter $(\mathrm{p}=0.01)$ and credit availability $(\mathrm{p}=0.005)$ were factors influencing marketing efficiency of the respondents. The study concluded that sheabutter marketing was a profitable enterprise in the study area. The study recommended that there should be proper awareness on the prospect of sheabutter business (either for local use or exportation) among young people; this will be an avenue to alleviate the scourge of unemployment in the country.
\end{abstract}

\section{DOI: https://dx.doi.org/10.4314/jasem.v25i4.27}

Copyright: Copyright $\odot 2021$ Olugbire et al. This is an open access article distributed under the Creative Commons Attribution License (CCL), which permits unrestricted use, distribution, and reproduction in any medium, provided the original work is properly cited.

Dates: Received: 03 February 2021; Revised: 26 March 2021; Accepted: 05 April 2021

Keywords: Sheabutter, marketing efficiency, marketing channels and Oyo state.

Shea trees Vitellaria paradoxa is a perennial crop that is usually found in the wild agro-forestry parklands across the semi-arid region of Africa, where annual rainfall ranges from 600 to $1500 \mathrm{~mm}$ (Enaberue et al., 2011). It occurs on an estimated $1,000,000 \mathrm{~km}^{2}$ area between western Senegal and northwestern Uganda. Nigeria accounts for $62 \%$ of the 600,000 metric tons produce in West Africa. Shea nuts play important socio-economic role in Nigeria in terms of employment and income generation to a significant proportion of rural population especially women who are, directly involved in shea nut collection and butter extraction (Matanmi et al., 2011). Sheabutter is a slightly yellowish or ivory colored fat extracted from the nut of African Shea tree, Vitellaria paradoxa (Aboyella, 2002). The Sheabutter market represent great potential for west African exporters but suppliers must provide a quality product and meet market requirement since disorganized export campaign and concern over quality have been found to hinder sales to import market (USAID, 2005). Three principal end users exist for Sheabutter which is the chocolate, cosmetics and natural product industry but cosmetics industry in Europe and United States are the second largest market segment for Sheabutter to West African suppliers because of the potential for direct sourcing (USAID, 2016). New market for Sheabutter exits in the personal care industry because of the recognition by the cosmetics industries (and its consumer) of the therapeutic benefit of Sheabutter (Adeyemo et al., 2015). The healing qualities of Sheabutter are due to the presence of several fatty acids and plant sterols, namely oleic, Stearic, Palmitic and Linolenic acids. These oil-soluble components are non-saponifiable, meaning they do not undergo saponification, or convert to soap, when introduced to an alkali. Sheabutter possesses a significantly greater nonsaponifiable fraction than most other nut oils and fats, which lends the substance greater healing potential for the skin (Fold, 2000). The demand for Sheabutter keeps increasing due to recent recognition of these beneficial properties by the markets in advanced countries. It is estimated that the amount of Sheabutter used in the western personal care market is about 10\% of the total African export with the demand in the United States considered to be growing at $25 \%$ per annum. Most recently it was reported that the dietary aid products have been developed from Sheabutter fractions for both human and animals, and US patents have been taken out for products that have lower cholesterol, reduced arthritis symptoms and have antidiarrheal properties. Despite the huge potential of Sheabutter demand in local, regional and international market, there is poor awareness of profitability and 
market structure of Sheabutter in Nigeria, most prospective investors do not consider Sheabutter marketing as an option, while much of the fruits are left uncollected, unutilized or totally inaccessible as unemployment plague the nation. This study aims at filling this gap. This study will also serve as awareness and guide for investors on the prospect of Sheabutter marketing in Nigeria. This work therefore looked into the structure, conduct and performance of sheabutter marketing in Oyo State Nigeria with a view to assisting policy makers in the inclusion of the product as a major resource that can boost the country's internally generated revenue if it is well harnessed. The objectives of the study are to examine the marketing practices and channels of honey distribution, analyse marketing efficiency of the respondents, determine the factors influencing marketing performance and identify the challenges to honey marketing activities in the study area.

\section{MATERIALS AND METHODS}

Study Area: The study was carried out in Oyo state situated in the South- western Nigeria. It is located between latitudes $7^{0} 3$ and $9^{0} 12$ North of the equator and longitudes $2^{0} 47^{\prime}$ and $4^{0} 23^{\prime}$ east of the Meridian. It is bounded on the West by Republic of Benin, on the North by Kwara State, on the East by Osun State and on the South by Ogun State. The state do experience two different seasons in a year, namely; wet season and dry season. The pattern of rainfall is noticeably steady ranging between $1,211 \mathrm{~mm}$ in the far North and $1,264 \mathrm{~mm}$ in the south at Ibadan in the last two decades. They early rainfall at average is calculated to be between $1,194 \mathrm{~mm}$ in the North and $1,278 \mathrm{~mm}$ in the South. The average temperature is $27^{\circ} \mathrm{C}$. The cultivation of tree crops such as cocoa, kola, oil palm and citrus as well as arable crops like maize, yam, cassava and rice is favoured in all parts of the state with high relative humidity. The state was purposively selected because of the prevalence of Shea butter marketers within the state (National Population commission, 2006 and Wikipedia).

Data Collection Method and Sampling Techniques: Primary data was used for this study. Data was collected by the use of well-structured interview schedule. A multi stage sampling techniques was employed for the study which involves three stages, at the first stage, purposive sampling was used to select three local government area out of the 33 LGAs in Oyo State which are Ibadan North L.G.A, Akinyele L.G.A and Saki West LGA based on a priori expectation that the three LGA has good markets for Sheabutter. The second stage involved a random selection of a market from each LGA namely- Bodija market from Ibadan North LGA, Shasha market from Akinyele LGA and
Sango market from Saki West LGA. The last stage involved random selection of equal number of 40 marketers both wholesalers and retailers from each market making a total of 120 marketers in all.

Method of Data Analysis: The analytical methods used in this study include descriptive statistics, marketing efficiency and multiple regression analysis.

Descriptive Statistics: This includes frequency table, means and percentages. Socio-economic characteristics like age, education qualification, marital status, household size, years of experience etc. were analyzed using descriptive statistics. Also, marketing activities and channels of distribution as well as challenges to marketing activities were analyzed through descriptive statistics.

Marketing Efficiency $(M E)$ : Marketing efficiency is a measure of market performance. Marketing efficiency most widely used measures are conventional output to input ratio; Shepherd's ratio of value (price) of marketed goods to the marketing cost (Shepherd, 1965); and Acharya's modified marketing efficiency formula (Acharya and Agarwal, 2001). However, all these measures do not consider explicitly the loss in the produce during the marketing process. As loss reduction in itself is one of the relevant parameters of efficiency, there is a necessity to give consideration to this factor expressly in the analysis to ameliorate marketing efficiency ratios measures used for the comparison of alternate markets or channels.

Empirical Assessment of Marketing Efficiency: Marketing efficiency (ME) is computed as:

OR

$$
\mathrm{ME}=\frac{\mathrm{TR}}{\mathrm{TC}} \times 100 \%
$$

$$
\mathrm{ME}=\frac{\mathrm{VAR}}{\mathrm{CM}} \times 100 \%
$$

Where When TR = total revenue; $\mathrm{TC}=$ total cost $\mathrm{CM}$ $=$ cost of marketing; $\mathrm{VAR}=$ Value added by respondent

Marketing efficiency can be defined as the maximization of the ratio of output to input in marketing. Efficient marketing optimizes the ratio between inputs and outputs. Marketing inputs here include the resources used in marketing of product whereas marketing output is the benefits or satisfaction created or the value added to the commodity as it moves through the marketing chain. Therefore for this study, value added by respondent is computed as Price (in received by the respondent 
(price paid by the consumers) less the price received by the preceding marketer in the supply chain.

Therefore:

$$
\mathrm{ME}=\frac{(T R-P C S)}{(\mathrm{TCM})} \times 100 \%
$$

Where TR $=$ total revenue; $\mathrm{PCS}-$ purchase cost of sheabutter, TCM = total cost of marketing. When ME $=100 \%$, it connotes that the respondent just recovered the cost incurred in carrying out the marketing services, when ME > 100\% implies that the respondent covered the cost of marketing and made a margin above the $100 \%$ (higher value of ME denotes higher level of efficiency), while $\mathrm{ME}<100 \%$ indicates that the respondent is operating at a loss.

Multiple Regression Analysis: This was used to estimate statistical relationship between market performance and socio economic characteristics of respondents. The use of ordinary least square (OLS) multiple regression analysis was made under the assumption that the data collected fulfilled the assumption of multiple regression model. These assumptions include absence of multicollinarity among independent variables, normally distributed error term with zero mean and constant variance and non-auto-regression disturbance (Kautsoyiannis, 1977). The general functional form postulated is implicitly presented by:

$\mathrm{Y}=\mathrm{F}\left(\mathrm{X}_{1}, \mathrm{X}_{2} \mathrm{X}_{3}, \mathrm{X}_{4}, \mathrm{X}_{5}, \mathrm{X}_{6}, \mathrm{X}_{7}, \mathrm{X}_{8}, \mathrm{X}_{9}, \mathrm{U}\right)$

Where; $\mathrm{Y}=$ Marketing Efficiency; $\mathrm{X}_{1}=$ Gender (male $=1$, female $=0$ ); $\mathrm{X}_{2}=$ Age; $\mathrm{X}_{3}=$ Household size (Actual)

$\mathrm{X}_{4}=$ Marital status ( single $=1$, married $=2$ ); $\mathrm{X}_{5}=$ Level of Education (Actual); $\mathrm{X}_{6}=$ Marketing experience (years)

$\mathrm{X}_{7}=$ Member of organization; $\mathrm{X}_{8}=$ Source of sheabutter (processors $=1$, from other marketing agents $=0$ ); $\mathrm{X}_{9}=$ Credit availability (Actual amount in Naira); $U$ =error term

\section{RESULTS AND DISCUSSION}

Socio-economic Characteristics of the Respondents: Table 1 showed that $110 \%$ of the respondents were female while the remaining $10 \%$ were male. This indicates that majority of sheabutter marketers in the area were female. This corroborates with Carette et al., (2009) study who reported that sheabutter business is women's. $5 \%$ of the respondents were less than or equal to $30 y e a r s$ of age, $50.6 \%$ of the respondents were between the age bracket of 31-40years, $36.6 \%$ of the respondents were between the age bracket of 41 $50 y e a r s, 5.9 \%$ of the respondents were between the age bracket of 51-60years and $1.6 \%$ of the respondents fell into the category of 61years and above. This indicates that majority of the marketers of sheabutter in the area are in their active age as the mean was found to be $35.5 y e a r s$. About $4.17 \%$ were single, $92.5 \%$ of the respondents were married and the remaining $1.67 \%$ of the respondents widowed. This indicates that majority of the marketers of sheabutter in the area were married people. This means that, married individuals are more committed to their responsibilities and work very hard to earn their living. This agrees with Olarinde et al., (2008) who reported that one of the most important factors that determines efficiency of a business is the marital status of an individual. This is because married people worked hard in order to meet up with the demand of the family members. The table further showed that about $31.6 \%$ of the respondents have a household size of less or equal to $5,60.8 \%$ of the respondents have a household size between the ranges $6-10$ and about $7.4 \%$ of the respondents have a household size ranging between 11-15. This indicates that majority of the marketers of sheabutter in this area have a household size that ranges between $6-10$. The mean was found to be 8 members. This is in agreement with Senchi and Yakubu who reported that large household size among sheabutter marketers and explained that there was readily available family labour thereby reducing the cost of hired labour in their business. Also, 23.3\% of the respondents have no access to formal education, $30.9 \%$ of the respondents had access to primary education, and $42.5 \%$ of the respondent had access to secondary education while the remaining $3.3 \%$ of the respondents had access to tertiary education. This indicates that most of the sheabutter marketers in the area had access to secondary education. $23.3 \%$ of the respondents spent less or equal to 5years in school, $30.9 \%$ of the respondents spent between 6 and 10years in school, while $42.5 \%$ of the respondents spent between 11 and 15years in school. This indicates that majority of the sheabutter marketers in the area spent between 11 and 15 years in school. The mean was found to be 13 years. This was supported by Farinde et al., (2005) who reported that education influences the adoption of new innovations, ideas or techniques in business operations they also revealed that education is positively related to the adoption of innovation. Majority (46.6\%) of the respondents were sheabutter producers while only $1.7 \%$ of the respondents were civil servant in the study area. $4.2 \%$ of the respondents had less or equal to 5years and 610 years of experience in shea butter marketing, $46.6 \%$ of the respondents had 11-15years of experience while $45 \%$ had 16-20 years of experience in marketing sheabutter. This implies that both experienced and inexperienced individuals were found among the 
respondents. The mean years of experience was found to be 13 years. About $68 \%$ of the respondents had an annual income between 200,001 and 800000 naira, $23.3 \%$ of the respondents had an income of less than 200,000 naira and only $8.4 \%$ had an income greater than 800,000 naira.

Table 1: Socio-economic Characteristics of Respondents

\begin{tabular}{|c|c|c|c|}
\hline Variables & Frequency & Percentage & Mean \\
\hline \multicolumn{4}{|l|}{ Gender } \\
\hline Female & 110 & 91.7 & \\
\hline Male & 10 & 8.3 & \\
\hline Total & 120 & 100 & \\
\hline \multicolumn{4}{|l|}{ Age of respondents } \\
\hline (years) & 6 & 5 & 35.5 \\
\hline$\leq 30$ & 61 & 50.6 & years \\
\hline $31-40$ & 44 & 36.6 & \\
\hline $41-50$ & 7 & 5.9 & \\
\hline $51-60$ & 2 & 1.6 & \\
\hline Above 60 & 120 & 100 & \\
\hline \multicolumn{4}{|l|}{ Total } \\
\hline \multicolumn{4}{|l|}{ Marital Status } \\
\hline Single & 5 & 4.17 & \\
\hline Married & 111 & 92.5 & \\
\hline Widowed & 2 & 1.67 & \\
\hline Total & 120 & 100 & \\
\hline \multicolumn{4}{|l|}{ Household size } \\
\hline$\leq 5$ & 38 & 31.6 & 8 \\
\hline $6-10$ & 73 & 60.8 & members \\
\hline $11-15$ & 9 & 7.4 & \\
\hline Total & 120 & 100 & \\
\hline \multicolumn{4}{|l|}{ Educational Level } \\
\hline No formal education & 28 & 23.3 & \\
\hline Primary education & 37 & 30.9 & \\
\hline Secondary education & 51 & 42.5 & \\
\hline Tertiary education & 4 & 3.3 & \\
\hline Total & 120 & 100 & \\
\hline
\end{tabular}

Table 1: Socio-economic Characteristics of Respondents (CONT.)

\begin{tabular}{|c|c|c|c|}
\hline \multicolumn{4}{|l|}{ Years of Schooling } \\
\hline$\leq 5$ years & 28 & 23.3 & 13 \\
\hline $6-10$ years & 37 & 30.9 & years \\
\hline $11-15$ years & 55 & 42.5 & \\
\hline 16 years and above & 0 & 0 & \\
\hline Total & 120 & 100 & \\
\hline \multicolumn{4}{|l|}{ Primary Occupation } \\
\hline Shea butter producer & 56 & 46.6 & \\
\hline Artisans & 17 & 14.2 & \\
\hline Trading & 45 & 37.5 & \\
\hline Civil service & 2 & 1.7 & \\
\hline Total & 120 & 100 & \\
\hline \multicolumn{4}{|l|}{ Marketing Experience } \\
\hline$\leq 5$ years & 5 & 4.2 & 13 \\
\hline$\overline{6}-10$ years & 5 & 4.2 & years \\
\hline $11-15$ years & 56 & 46.6 & \\
\hline $16-20$ years & 54 & 45 & \\
\hline Total & 120 & 100 & \\
\hline \multicolumn{4}{|c|}{ Annual income from } \\
\hline sheabutter per annum ( & 28 & 23.3 & \\
\hline$<200,000$ & 82 & 68.3 & \\
\hline $200,001-800,000$ & 10 & 8.4 & \\
\hline$>800000$ & 120 & 100 & \\
\hline Total & & & \\
\hline
\end{tabular}

Marketing Practices and Channel of Sheabutter Distribution: Table 2 showed that most (97.5\%) of the respondents source their capital from personal savings, while $31.7 \%$ of the respondents got their capital from cooperative society, $5.8 \%$ from relatives and friends, $5 \%$ of the respondents got their capital from micro finance and only $2.5 \%$ of the respondents from commercial banks. The study revealed that $85.5 \%$ of marketers got their sheabutter from direct producers, $24.2 \%$ from sheabutter wholesalers and $15 \%$ from shea butter retailers. Storage of sheabutter revealed that most of the respondents $(95.8 \%)$ used plastic containers to store their shea butter while $54.2 \%$ use stainless basins and only $27.5 \%$ used pots to store their sheabutter. The finding reveals that most of the respondents used plastic containers to store their sheabutter. The study further revealed that only $8.3 \%$ of the respondents advertise their sheabutter business and majority $(91.7 \%)$ of the respondents do not advertise their business. $75 \%$ of the respondents do not brand their shea butter before marketing, $16.7 \%$ use containers and labels while $8.3 \%$ use customized containers. This finding reveals that most of the respondents do not brand the product which suggest that advertisement is not done. $57.5 \%$ of the respondents used family labour, $22.5 \%$ used hired labour while $20 \%$ used both family and hired labour. The findings of the study also indicate that majority of the respondents in the study area used family labour in performing marketing activities.

Table 2: Marketing Practices and Channels of Sheabutter

\begin{tabular}{lll}
\multicolumn{3}{c}{ Distribution } \\
\hline Variables & Frequency & Percentage \\
Source of Fund & & \\
Personal savings & 117 & 97.5 \\
Relatives/Friends & 7 & 5.8 \\
Micro finance & 6 & 5 \\
Cooperative society & 38 & 31.7 \\
Commercial Bank & 3 & 2.5 \\
Total & $* 292$ & \\
Source of sheabutter & & \\
Direct producers & 103 & 85.8 \\
Buy from wholesalers & 29 & 24.2 \\
Buy from retailers & 18 & 15 \\
Total & $* 150$ & \\
Storage Type & & \\
Pots & 33 & 27.5 \\
Plastic containers & 115 & 95.8 \\
Stainless Basins & 65 & 54.2 \\
Total & $* 213$ & \\
Packaging material & & \\
Plastic containers & 60 & 50 \\
Nylon & 101 & 84.2 \\
Total & $* 224$ & \\
Advertisement & & \\
No & 110 & 91.7 \\
Yes & 10 & 8.3 \\
Total & 120 & 100 \\
*Multiple response; Source: Calculations from field survey
\end{tabular}

This will enhance them to spend little on labour cost and increase their performance which may therefore bring an increase in the level of the marketer's income. This corroborates the findings of Adeola, (2011) 
where majority of the respondents used family labour for their marketing activities. Marketing efficiency of the respondents increases with increase in household size. This means the more the family size, the less respondents spend on labour cost, as household members help in marketing activities. The result also shows that majority $(82.5 \%)$ of the respondents belong to an association while $17.5 \%$ do not belong to any association. This is in agreement with Adesope A. A et al., (2019) study which stated that most of the sheabutter marketers belong to an association.

Table 2: Marketing Practices and Channels of Sheabutter Distribution (CONT.)

\begin{tabular}{lll}
\hline \multicolumn{2}{c}{ Branding method } & \\
Customized containers & 10 & 8.3 \\
Containers and label & 20 & 16.7 \\
Others ( no branding) & 90 & 75 \\
Total & 120 & 100 \\
Labour used & & \\
Family labour & 69 & 57.5 \\
Hired labour & 27 & 22.5 \\
Family and hired labour & 24 & 20 \\
Total & 120 & 100 \\
Membership of association & & \\
Yes & 99 & 82.5 \\
No & 21 & 17.5 \\
Total & 120 & 100 \\
\hline Multiple response; Source: Calculations from field survey.
\end{tabular}

Market Efficiency Analysis (performance): Since the Marketing Efficiency (ME) is > $100 \%$, this implies that the respondent covered the cost of marketing and made a margin above the $100 \%$, hence shea butter marketing is efficient in the study area.

\begin{tabular}{ll}
\multicolumn{3}{c}{ Table 3: Marketing Efficiency (performance) } \\
\hline Variable & Amount \\
Total Revenue (TR) & $9,504,000.00$ \\
Total Cost (TC) & $7,051,754.15$ \\
Marketing Efficiency (ME) & $135 \%$ \\
\hline \multicolumn{2}{c}{ Source: Calculations from field survey }
\end{tabular}

Factors Influencing Marketing Efficiency (Performance): Table 4 shows that semi log functional form is fitted in the estimation of ordinary least square regression. $\mathrm{R}^{2}$ of $0.84 \%$ indicated that the model specify could explain up to $84 \%$ of variation in the dependent variable included in the model. The estimated regression coefficient of household size was significant at $5 \%$ and positively related to marketing efficiency. This implies that a unit increase in the variables will increase the efficiency of sheabutter marketeering. This means that the more the family size, the less the respondents spend on labour cost because household members help in marketing activities. This contradicts the finds of Cadot et al (2006) who explained that large households seem to have higher opportunity costs, perhaps which is reflected in the fact that they have lower per-capita income and hence less surplus to purchase capital equipment to switch to the market. Credit availability was also significant at $5 \%$ and positively related to marketing efficiency. This implies that the variable contributes to the market efficiency of sheabutter which suggest that there is increase in profit of sheabutter is as a result of capital (credit) availability for business expansion. Also, marketing experience was positive and significant at $1 \%$. This implies that increase in years of experience would increase the efficiency of shea butter marketers. This is in agreement with Deng et al. (2017) who also observed a positive effect of experience on sheabutter profitability. Member of organization was found to be positive and significant at $1 \%$ probability. This is corroborates with Tijani (2018) who reported that the plausible reason for the significant relationship between membership in association and market efficiency could be attributed to the fact that group dynamics creates synergy among the respondents and enables them to access market information as well as share experiences. Abera (2009) stated that group dynamics facilitate access to improved technology, training and output markets and consequently increasing expected profits. Source of sheabutter was positively significant at $10 \%$ level of probability.

\begin{tabular}{|c|c|c|c|}
\hline Variable & Coefficient & $\begin{array}{l}\text { Standard } \\
\text { Error }\end{array}$ & t-value \\
\hline Gender & -1.608 & 18.697 & -0.086 \\
\hline Age & -1.984 & 2.031 & -0.977 \\
\hline Household size & 0.304 & 0.148 & $2.056^{* *}$ \\
\hline Marital Status & -13.607 & 14.338 & -0.949 \\
\hline Level of Education & 0.042 & 0.091 & 0.461 \\
\hline $\begin{array}{l}\text { Marketing } \\
\text { experience }\end{array}$ & 0.221 & 0.034 & $6.367 * * *$ \\
\hline $\begin{array}{l}\text { Member } \\
\text { organization }\end{array}$ & 0.388 & 0.063 & $6.158 * * *$ \\
\hline Source of sheabutter & 0.501 & 0.198 & $2.528^{*}$ \\
\hline Credit availability & 0.016 & 0.014 & $1.177 * *$ \\
\hline Constant & 4.550 & 7.837 & 0.581 \\
\hline
\end{tabular}

Challenges of Sheabutter Marketing: Table 5 showed that $92 \%$ of the respondents mentioned that their major challenge is scarcity of shea butter due to deforestation problems. This corroborates with finds of Adesope et al., (2019) and Senchi \&Yakubu (2014) who reported that scarcity of shea nuts for processing into shea butter was as a result of deforestation of the shea tree, they further said that the shea trees produce best quality charcoal as such a lot of people are more concern in producing quality charcoal in most part of the areas. This implies that there are alternative uses of shea butter trees that are competing with shea butter production. $75 \%$ of the respondents said that lack of 
capital was a major problem in shea butter marketing this is in agreement with Senchi \&Yakubu (2014) who reported that lack of capital was a major problem in shea butter marketing. Also $65 \%$ of the respondents said inadequate storage and preservation was a major challenge. This agrees with the study of Adeyemo et al., (2015) and Tanko M (2017) who reported that poor storage and preservation was a major constraint in marketing of shea butter. $57.5 \%$ of the respondents also said that transportation was a major constraints encountered in the marketing of shea butter. This is in agreement with Senchi \&Yakubu (2014) who reported that transportation problem was a major constraint in marketing of shea butter because many of the roads in rural areas were the state of disrepair. $48.3 \%$ of the respondents said unstable market price was a major constraints while only $15.85 \%$ of the respondents said low demand was major constraints in the marketing of shea butter.

Table 5: Frequency distribution of the respondent based on their

\begin{tabular}{lll}
\multicolumn{3}{c}{ challenges } \\
\hline Variables & *Frequency & Percentage \\
\hline Credit Unavailability & 90 & 75 \\
Transportation problem & 69 & 57.5 \\
Adulteration & 33 & 27.5 \\
Unstable market price & 58 & 48.3 \\
Inadequate Storage and & 78 & 65 \\
preservation & & \\
Low demand & 19 & 15.8 \\
Unavailability/Scarcity & 110 & 91.7 \\
due to deforestation & & \\
problem & & \\
\hline *Multiple response. Source: Calculations from field survey.
\end{tabular}

Conclusion: Shea butter marketing seems to operate in a competitive atmosphere as there was patronage both within and outside the areas. This suggests that shea butter marketing is profitable in the study area. Based on the finding that unavailability of shea butter as a result of deforestation and the implication of deforestation is that it would lead the shea trees to extinction, there should be awareness creation on stopping deforestation and afforestation programmes should be embraced to ensure the shea trees would be safe from the danger of being extinct. Finally, there should be creation of proper awareness on the prospect of shea butter exportation (either for local use or exportation) business among young people; this will be an avenue to alleviate the scourge of unemployment in the study area and in the country at large.

\section{REFERENCES}

Abera, G. (2009): Commercialization of Smallholder Farming: Determinants and Welfare Outcomes. A Cross Sectional Study in Enderta District, Tigrai Ethiopia. Masters Thesis, The University of Agder, Kristiansand.
Aboyella, G. E. (2002): Economic Analysis of Shea nut and Cashew Production in Bakwu East District. TIJOSS. 6 (4) 123-130, 2002.

Acharya, S.S. and Agarwal, N.L. (2007): Agricultural Marketing in India, Oxford and IBH Publishing Co., New Delhi, pp. 385-417.

Adeola A.O, Bifarin, J. and Folayan J. A (2011): Honey Marketing in Ibadan Metropolis of Oyo State, Nigeria: An Economic Analysis. JOAS. 2(2): 113-119.

Adesope A. A, Opute O.H, Bello K.G and Pitan O.O (2019): Economic Analysis of Shea Butter Production in Oke Ogun Area of Oyo State, Nigeria. IOSR-JEF. 10. 2 Ser. III

Adeyemo R., Oke J.T, Owombo P.T and Lanlokun O. (2015): Economic Efficiency of Shea butter Production in Oyo State, Nigeria. IJARD. 18 (1). 17-23.

Arthur, A. A, Adraki, P.K and Allotey, S.S (2018): Value Chain Interventions and Business Performance: A study of Beneficiary Shea Value Chain Actors in Northern Region, Ghana. IJAEE, 4(1). 101-113, March, 2018.

Carette C, Malotaux M, Leeuwen M and Tolkamp M (2009): Shea nut and butter in Ghana opportunities and constraints for local processing. Hans Eenhoorn and Resilience Foundation. pp.68. http://www.resiliencefoundation.nl/docs/Shea.pdf.

Chibor B.S, Kiin-Kabari D.B and Eke-Ejiofor J. (2017): Physicochemical Properties and Fatty Acid Profile of Shea Butter and Fluted Pumpkin Seed Oil: A Suitable Blend in Bakery Fat Production. IJNFS. 6(3). 122-128.

Deng, S. Y. M., Dossou, T. N., \& Tanko, M. (2017): Profitability analysis of shea butter in Northern Region of Ghana. IJRD, 2(3). 22-27.

Enaberue L.O, Okolo E.C and Yusuf A.O (2011): Phenotypic variation of Vitellaria paradoxa (shea butter tree) in Agroforestry Parkland of Nigeria guinea savanna. J. Appl. Agric. Res. 3:203-209

Farinde A. J, Soyebo K.O and Oyedekun M.O (2005): Exploration of beekeeping as a coping strategy in a deregulated economy. JAE. 8. 76-83 
Fold N (2000): A matter of good taste. Quality and the construction of standards for chocolate in the European Union. CESR. 55/56 (4) 92-110,

Godfred S.J., Osamu S. and Kazuhiko T. (2015): Shea (Vitellaria Paradoxa) Butter Production and Resource Use by Urban \& Rural Processors in Northern Ghana. Sustainability, 7: 3592-3614.

Koutsoyiannis A (1977): Theory of Econometrics. London: The Macmillan Press Ltd.

Matanmi B.M, Adesiji G.B, Olasheinde E.M, Oladipo F.O (2011): Assessment of usage of upgraded indigenous shea butter processing technology by women processors in Kwara State, Nigeria. Agrosearch www.ajol.info/index.php/agrosh/article/view/7505 $\underline{4}$

Michail N.G, Adamantia G. P, Ilias O. P (2011): Identifying the Direct Effect of Experience and the Moderating Effect of Satisfaction in the Greek Online Market. IJESMA 3 (2). 39-58

NC (2006): National Population Commission Report, Abuja, Nigeria

Olarinde L. O, Ajao A.O and Okunola S.O (2008): Determinants of technical efficiency in beekeeping farms in Oyo State, Nigeria. A Stochastic frontier approach. Res. J. Agric. \& Biol. Sci. 4(1). 65-69,

Olugbire O.O, Fakunle A.J, Opute O.H, Oke D.O, Obafunsho O.A, Kolade R.I and Oguntoye T.O (2020): Economic Analysis of Shea Butter Marketing in Oyo State, Nigeria. EconEurasia Journal. 10(40), 1-7
Philip K, Gary A, John S and Veronica W (1999): Principles of Marketing; second European Edition Published; ISBN0-13- 26225 PP 4-8.

Senchi A. A and Yakubu A. A (2014): Assessment of Processors and Marketers of Sheabutter (Vitellaria Paradoxa C. F. Gaertn.) in Zuru Local Government Area, Kebbi State, Nigeria. JRFWE 6, (2).22-34

Tanko M (2017): Profit efficiency and constraints analysis of shea butter industry: Northern region of Ghana. KJOAS. 44(2). 1-16

Tiamiyu S.A, Adagba M.A and Shaahu A (2014): Profitability analysis of shea nuts supply chain in selected states in Nigeria. JACR 2(12). 222-227,

Tijani S.A (2018): Determinants of Market Participation among Small Scale Shea Butter Processors in Kwara State, Nigeria. TAJAS. 1. (1). $1-10$

Shepherd, A. W. 2006. Approaches to link producers to Markets- A Review of Experiences to Date, Agricultural Management, Marketing and Finance, Occasional paper No. 13, Rome, FAO.

United States Agency for International Development (USAID) (2005). Buying and Selling Shea butter, a Marketing Manual for West Africa. Fintac Inc.

United State Agency for International Development (USAID) (2016) Shea: Nigeria Loses 350 billion naira to Shea Smuggling Annually. Www.nigerianextt.org. Retrieved on 22nd August, 2016. 